\title{
Nanostructures and properties of an Oxisol under no-tillage and mechanical
}

\section{chiseling}

Nanoestruturas e propriedades de um Latossolo Vermelho sob plantio direto e escarificação mecânica

Nanoestructuras y propiedades de uno Oxisol en labranza cero y cincelado mecánico

\begin{abstract}
Soil compaction in no-tillage systems (NTS) affects the sustainability of this management. To overcome the problem, mechanical chiseling and maintenance of the vegetation cover suggested were as management practices in order toreestablish ideal cultivation conditions. The soil studied was occupied for 20 years with annual crops in conventional tillage system (plowing and leveling harrow). After, the NTS was implemented for 15 years old. In 2012, management were implemented to study the effects on soil quality, with mechanical chiseling, cover crops, rice and bean. Thepurpose of this study was to evaluate the effect of soil chiseling and the use of cover crops on the maintenance of NTS sustainability after a crop succession of rice and common bean on a clayed Orthic Ferralsol. After four years we evaluation were then carried out to analyze the effects of the system on the soil quality physical and chemical attributes. We studied five cover plants (Crotalaria juncea; Cajanus cajan; Pennisetum glaucum; Urochloa ruziziensis and Fallow) all in NTS with and without chiseling. In addition, we studied a natural Savannah fragment too. Chiseling with cultivation of Crotalaria juncea as vegetation cover improved the physical properties compared with the initial conditions. However, cover crops grown on unchiseled soil resulted in an increase in the chemical properties $\mathrm{P}, \mathrm{K}$, and $\mathrm{Mg}$ concentrations, $\mathrm{pH}$, and soil organic matter. The soil nanostructures morphological characteristics is a promising indicator it quality, complementary to the chemical indicators, for being sensitive enough for the short-term detection of changes soil properties.
\end{abstract}

Keywords: Nanotechnology; Organo-mineral associations; Soil compaction; Cover crops; Soil structure.

\section{Resumo}

A compactação do solo em sistemas de plantio direto (SPD) afeta a sustentabilidade desse manejo. Para contornar o problema, a escarificação mecânica e a manutenção da cobertura vegetal foram as práticas de manejo estudadas para restabelecer as condições ideais de cultivo. O solo foi cultivado por 20 anos com lavouras anuais em sistema de preparo convencional (aração e grade niveladora). Depois, foi utilizado por 15 anos com SPD. Em 2012, foram implantados manejos com o objetivo de estudar os efeitos na qualidade do solo, com escarificação mecânica, plantas de cobertura, arroz e feijão. Após quatro anos foram analisados os efeitos do sistema na qualidade dos atributos físicos e químicos do solo. Foram estudadas cinco plantas de cobertura (Crotalaria juncea; Cajanus cajan; Pennisetum glaucum; Urochloa ruziziensis e Pousio) todas em SPD, com e sem escarificação. Como testemunha foi utilizado um solo de fragmento natural de Cerrado. A escarificação com cultivo de Crotalaria juncea como cobertura vegetal 
melhorou as propriedades físicas em comparação com as condições iniciais. No entanto, as plantas de cobertura cultivadas em solo não escarificado resultaram em aumento nas concentrações de $\mathrm{P}, \mathrm{K}$ e $\mathrm{Mg}$, bem como do $\mathrm{pH}$ e matéria orgânica do solo. As características morfológicas das nanoestruturas do solo são um indicador promissor de qualidade, complementar aos indicadores químicos, por serem sensíveis para a detecção a curto prazo, de alterações nas suas propriedades físicas.

Palavras-chave: Nanotecnologia; Associações organo-minerais; Compactação do solo; Plantas de cobertura; Estrutura do solo.

\section{Resumen}

La compactación del suelo en sistemas de labranza cero (SLC) afecta la sostenibilidad de este manejo. Para superar el problema, se sugirió el cincelado mecánico y el mantenimiento de la cubierta vegetal como prácticas de manejo para restablecer las condiciones ideales de cultivo. El suelo estudiado estuvo ocupado durante 20 años con cultivos anuales en sistema de labranza convencional (arado y rastra niveladora). Después, con el SLC durante 15 años. En 2012 se implementó manejo para estudiar los efectos en la calidad del suelo, con cincelado mecánico, cultivos de plantas de cubierta, arroz y frijol. Después de cuatro años, se realizó una evaluación para analizar los efectos del sistema en la calidad de los atributos físicos y químicos del suelo. Se estudiaron cinco plantas de cubierta (Crotalaria juncea; Cajanus cajan; Pennisetum glaucum; Urochloa ruziziensis y barbecho) todas en SLC con y sin cincelado. También estudiamos uno fragmento de Savannah natural. El cincelado con cultivo de Crotalaria juncea como cubierta vegetal mejoró las propiedades físicas en comparación con las condiciones iniciales. Sin embargo, los cultivos de cubierta cultivados en suelo sin cincelar dieron como resultado un aumento en las propiedades químicas, concentraciones de $\mathrm{P}$, $\mathrm{K}$ y $\mathrm{Mg}$, pH y materia orgánica del suelo. Las características morfológicas de las nanoestructuras del suelo son un indicador prometedor de su calidad, complementario a los indicadores químicos, por ser suficientemente sensibles para la detección a corto plazo de cambios en las propiedades fisicas del suelo.

Palabras clave: Nanotecnología; Asociaciones organominerales; Compactación del suelo; Cultivos de cubierta; Estructura del suelo.

\section{Introduction}

The establishment of a competitive production system of the Brazilian agriculture depends on the adoption and maintenance of agricultural practices based on sustainable bases. Among the different agricultural practices, the no-tillage system (NTS) is noteworthy, for being a conservation management, based on absence of tillage, use of crop rotation, and maintenance of a permanent soil cover (Alves et al., 2015; Mateus \& Santos, 2012).

Despite the numerous benefits for the soil, the installation of long-term NTS has caused problems with soil compaction (Mioranza et al., 2015). This is particularly true in irrigated areas, where the land use is intensive, with increased traffic of heavy machinery due to the number of agricultural operations, often carried out at excessive soil moisture levels. According to (Freddi et al., 2007), soil compaction alters the soil bulk density and porosity, limiting root development, hampering the water and nutrient uptake by crops, ultimately affecting the sustainability of no-tillage systems (Silva et al., 2004).

To overcome the deleterious effects of soil compaction, some strategies in long-term NTS have been suggested, e.g., mechanical chiseling (Seki et al., 2015) and biological chiseling by the cultivation of cover crops (Nicoloso et al., 2008).

The choice of the cover crop species is a fundamental factor for the implementation and maintenance of NTS in the Savannah area, since in this region the climatic conditions interfere with the speed of crop residue decomposition (Costa et al., 2014), influencing the function of soil protection and dynamics of nutrient release to the system (Calonego et al., 2012). In this choice, the size of the root system must be taken into account, since deep systems can promote biological chiseling, which occurs by root penetration into the compacted layer, creating small vertical cracks, altering the soil physical properties (Chen \& Weil, 2010).

Mechanical chiseling of the soil consists of breaking the compacted layer by means of fine rods, altering the physical properties of this layer (Reichert et al., 2009). However, the effects were described as not very durable (Drescher et al., 2011; Nunes et al., 2014). These effects are according with Secco et al. (2021) because they write that chiseling soil management 
decreased soil bulk density and increased total porosity, but chiseling had short-term effects on soil physical properties (12 months), and the cover crops showed no difference regarding the effects on soil physical properties.

Even when soil management strategies adopted are to repair or establish desirable conditions for cultivation, the expected changes cannot detected be immediately or the forms of evaluation are not sensitive enough to detect these changes. According to Tang et al. (2009), most of the transformation processes in soils occur due to the interactions of colloidal particles in the soil. Soils contain heterogeneous mixtures of organic particles and inorganic solids, with sizes ranging from the millimeter to the nanometer scale. At nanometric scales, the atomic structure at the surface and near the surface of soil particles can differ, as well as the shape and surface topography of the crystal, as a function of its size at this scale (Hochella et al., 2008). Therefore, these variations can make a difference in the kinetics and in mechanisms of important geochemical and biogeochemical reactions.

Javed et al. (2019) report the importance of nanotechnology for agriculture both for understanding the interactions of nanoparticles in soil behavior and maintaining their health, as well as in the addition of nanoparticles to the soil through herbicides, pesticides and fertilizers. With the application of nanoparticles enhancing the soil fertility and supporting organic cycles in the soil, the microbial activity is enhanced which helps in addressing the wastelands, infertile lands and toxic landscapes to support vegetation and farming. In the existing croplands, the nanoparticles mediated nanofertilizers support in increasing the fertility and crop growth. Overall, nanotechnology provides the efficiency of the agriculture for a higher population.

Nanotechnology has been studied in other sciences, such as in geotechnical engineering. Arora et al. (2019) write that TEM (transmission electron microscope) is one of the techniques that can be used, when the structure of fine-grained soil is studied at nanoscale level so special equipment is needed. This technique is used to recognize the measurement, shape and morphology of the soil particles so that their structural integrity for strength can be found. So the images of nanparticles and nanostructures which provides in the soil matrix can be visualized.

In a study of clay nanoparticles of a Chile an Andisol Calabi-Floody et al. (2011) found that the characterization of soils at the nanoscale can contribute to a better understanding of the components and mechanisms involved in the: stabilization of soil organic matter (SOM) and of its chemical quality as well as of the interactions of natural soil nanoparticles with the transport and persistence of the xenobiotics they contain.

In this sense, some studies have investigated the role of iron oxides, aluminum hydroxide and kaolinites in the interaction with organic matter and its stability (Shen, 1999; Pédrot et al., 2011; Keiluweit et al., 2012; Ghezzi et al., 2014; Adhikari \& Yang, 2015; Feng et al., 2015). According to Vendrame et al. (2011), these minerals are abundant in the composition of Savannah soils, therefore, it is of paramount importance to study the behavior of the nanoparticles of these soils to deepen the understanding of how management practices are affecting these soils.

The characterization of soil nanoparticles by means of electron microscopy has had promising results, for providing information about the morphology of these nanoparticles, improving the understanding of the mechanisms by which they are linked (Keiluweit et al., 2012; Ghezzi et al., 2014; Archanjo et al., 2017).

Considering the above measures of maintenance of NTS and the difficult detection of alterations caused by these managements and of the diverse processes and mechanisms in which the soil nanostructures participate, this study had the objective of evaluating the effect of chiseling and the use of different cover crops on the maintenance of the sustainability of NTS. To this end, these effects on the soil monitored were through physical and chemical indicators and by the morphology of soil nanostructures. 


\section{Methodology}

The experiment was conducted in Selvíria, Mato Grosso do Sul, Brazil (20 18 'S and $\left.51^{\circ} 22^{\prime} \mathrm{W}\right)$, at an altitude of $335 \mathrm{~m}$ in an area under (central pivot) irrigation, of the São Paulo State University, School of Engineering, Ilha Solteira, on a typical clayey Orthic Ferralsol (Oxisol) dystrophic (WRB-IUSS, 2015). The mean annual values of precipitation, temperature and relative humidity are, respectively, $1370 \mathrm{~mm}, 23.5^{\circ} \mathrm{C}$ and $66 \%$. The climatic type, according to Köppen is Aw (humid tropical climate, with rainy summers and drought in the winter).

The area where installed the treatments was originally occupied by Cerrado vegetation (Savannah) and now used for agricultural exploitation under NTS since more than 15 years, with rice, common bean, soybean and maize cultivation. Prior to the experiment, the chemical and physical properties of the $0-0.05 \mathrm{~m}$ soil layer (Table 1) were determined.

The NTS treatments consisted of two conditions of the soil surface: under no-tillage with and without mechanical chiseling - combined with four cover crops adapted to the Cerrado conditions (Santos et al., 2012; Nascimento et al., 2016). In 2012, after 15 years of no-tillage, treatments were implemented to study the effects on soil quality, with mechanical chiseling of the area, sowing of cover crops and upland rice. After the cultivation of rice (agricultural year 2012/13), "winter" beans were sown. About the cover crops, two of which were legumes: Crotalaria juncea and Cajanus cajan and two were grass crops: Pennisetum glaucum and Urochloa ruziziensis, plus a fallow treatment (spontaneous vegetation in the area with mostly Ipomoea purpurea, Bidens pilosa, Conyzabon ariensis, Commelia benghalensis, and Digitaria sanguinalis). These crops were planted in treatments as follows: T1 = Crotalaria juncea in NTS without chiseling; T2 = Crotalaria juncea in NTS with chiseling; T3 = Cajanus cajan in NTS without chiseling; T4 = Cajanus cajan in NTS with chiseling; T5 = Pennisetum glaucum in NTS without chiseling; T6 = Pennisetum glaucum in NTS with chiseling; T7 = Fallow in NTS without chiseling; T8 = Fallow in NTS with chiseling; T9 = Urochloa ruziziensis in NTS without chiseling and T10 = Urochloa ruziziensis in NTS with chiseling. An additional treatment consisting of a natural Cerrado fragment (Savannah) (T11).

The NTS chiseled area was with a scarified with rods spaced $0.3 \mathrm{~m}$ apart, reaching a depth of $0.3 \mathrm{~m}$. After three days, we planted the cover crops in the areas with and without chiseling, in rows spaced $0.45 \mathrm{~m}$ apart, without fertilization, with a seed drill. At 63 days after sowing, the cover crops were herbicide-desiccated with glyphosate $\left(1440 \mathrm{~g} \mathrm{ia} \mathrm{ha}^{-1}\right)+2.4-\mathrm{D}(670 \mathrm{~g}$ ia $\mathrm{ha}^{-1}$ ) and then the plants were broken with a crop roller cutter. Then the main crops rice (cv. BRS Esmeralda) and common bean were planted in succession, at a row spacing of $0.35 \mathrm{~m}$ and $0.40 \mathrm{~m}$, respectively.

Disturbed soil samples were collected after one year the implanted the research from the 0.0-0.05m layer after common bean harvest, at five points per plot within each treatment area, to form a composite sample. After sampling, we crumbled the material, dried at room temperature and then sieved through a $2.00 \mathrm{~mm}$ sieve (air-dried fine soil -ADFS). After preparing these samples, we analyzed the morphological characteristics of the nanoparticles and nanostructures and the chemical properties of the soil. For the analysis of the soil physical properties, such as total porosity, macroporosity, microporosity, and soil bulk density, collected the undisturbed samples in metal rings $\left(70 \mathrm{~cm}^{3}\right)$ from the same soil layer, at three points per plot.

For the morphological characterization of soil nanoparticles and nanostructures, firstly ADFS dispersed. Glass flasks were filled with10 $\mathrm{g}$ of ADFS and 200mL of ultrapure water, purified with a Mega RO/UP - Mega Purity system, at an electrical conductivity of 0.4 to $0.7 \mu \mathrm{S} \mathrm{cm}^{-1}$. This solution slowly stirred for $16 \mathrm{~h}$ using an end-over-end shaker. There after the solutions subjected to sonification for $5 \mathrm{~min}$ at $80 \%$ amplitude, for dispersion of soil particles. Sonication was performed with an ultrasonic device (VC 500, SONICS \& MATERIALS®), by inserting a $19 \mathrm{~mm}$ diameter probe to a depth of $35 \mathrm{~mm}$ of the solution (Edwards and Bremmer, 1967; Sá and Lima, 2005). During sonification, the glass bottle was maintained in an ice bath to minimize the temperature, as suggested by Ribeiro et al. (2014). From the sonicated solution, 70mL was to transfer in a 
pipette immersed $10 \mathrm{~mm}$, to two Falcon tubes. Subsequently, the volume withdrawn from the flask was replenished with ultrapure water, and sonification was repeated three more times (Souto Filho et al., 2017).

Table 1. Soil chemical and physical properties in the experimental area, prior to the experiment, in the studied layer. Selvíria, Mato Grosso do Sul, Brazil.

Chemical properties

\begin{tabular}{|c|c|c|c|c|c|c|c|c|c|c|c|}
\hline $\mathbf{P}$ & SOM & pH & $\mathbf{K}$ & $\mathbf{C a}$ & Mg & $\mathbf{H}+\mathbf{A l}$ & $\mathbf{A l}$ & SB & CEC & $\mathbf{V}$ & $\mathbf{m}$ \\
\hline $\mathrm{mg} \mathrm{dm}$ & $\mathrm{g} \mathrm{dm}^{-3}$ & $\mathrm{CaCl}_{2}$ & --- & 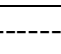 & - & ------mr & $-\ldots$ & -- & & $\%$ & $\%$ \\
\hline 29 & 24 & 5.9 & 3.5 & 41 & 25 & 19 & 0 & 69.5 & 88.5 & 79 & 0 \\
\hline
\end{tabular}

Physical properties

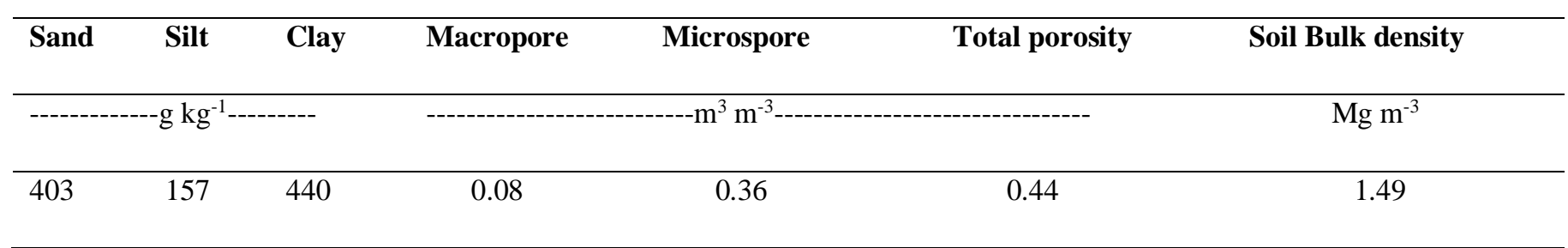

P: available phosphorus (resin); SOM: Organic matter; K, Ca Mg exchangeable H+Al: potential acidity; SB: Sum of bases; CEC: cation exchange capacity; $\mathrm{V}(\%)$ : base saturation; $\mathrm{m}(\%)$ : aluminum saturation; $\mathrm{pH}$ : Hydrogenionic potential. Source: Authors.

The solutions collected during sonication were subsequently centrifuged (model NT 815, NOVATECNICA ®) for 36 min at $4,970 \mathrm{rpm}$ at $20^{\circ} \mathrm{C}$, to separate structures and particles smaller than 200nm (Ghezzi et al., 2014). After centrifugation, 25 $\mathrm{mL}$ of the supernatant was removed and filled in a plastic jar at $4^{\circ} \mathrm{C}$ (Tang et al., 2009). To avoid that the material deposited at the bottom of the tube also with drawn when collecting the supernatant, a pipette was used, immersed $5 \mathrm{~mm}$ into the solution.

The supernatant was diluted 1:10 in ultrapure distilled water. Three drops of the dilution were then to deposit on a 200-mesh $\mathrm{Cu}$ grid. Thereafter, the grids were to place on filter paper, dried at room temperature for $24 \mathrm{~h}$ and during this period, protected in closed Petri dishes to avoid contamination of external agents in suspension in the environment. After preparing the samples in this way a transmission electron microscope TECNAI TM G2 F20 (HRTEM), operated at $200 \mathrm{kV}$, was used to take micrographs of the nanoparticles and the soil nanostructures, in the laboratory of structural characterization (LCE) of the Universidade Federal de São Carlos (UFSCar). Micrographs taken at three random points along the grid magnified 79,000, 160,000 and 450,000 x.

The morphological characteristics of the soil nanoparticles and nanostructures of each treatment were obtained from the micrographs analyzed through software Image J (Schneider et al., 2012). The following characteristics analyzed were area, perimeter, size, and circularity of the soil nanoparticles. To determine the size of the nanoparticles, the Feret diameter (distance between two tangents parallel to the contour of the particle) was used and the circularity was used to describe the particle shape (Rice et al., 2013).

For the analysis of the soil physical properties, the undisturbed samples saturated by capillarity in a tray until reaching $2 / 3$ of the height of the soil sample rings, for $24 \mathrm{~h}$. Total porosity was determined by filling the pores completely with water. The saturated samples were subjected to a tension table at a pressure of $0.060 \mathrm{kPa}$, to determine macroporos (pores $\geq 0.05 \mathrm{~mm}$ ) and micropores (pores $<0.05 \mathrm{~mm}$ ). Macroporosity estimated by the difference in the water volume of water-saturated samples, before and after using a tension table. Bulk density was determined by the volumetric ring method, in which the same samples 
collected to characterize porosity were dried at $105^{\circ} \mathrm{C}$ for $24 \mathrm{~h}$ (Claessen, 1997).

The soil chemical properties were analyzed by the methodology described by Raij et al. (2001) where potassium (K), calcium $(\mathrm{Ca})$ and magnesium $(\mathrm{Mg})$ were extracted by the ion exchange resin and determined by an atomic absorption spectrophotometry (SpectrAA 55B, VARIAN $($ ). Phosphorus $(\mathrm{P})$ extracted by ion exchange resin and determined by spectrophotometer colorimetry (Cary 50, VARIAN®). Potential acidity $(\mathrm{H}+\mathrm{Al})$ was determined by titration using $0.5 \mathrm{molL}^{-1}$ calcium acetate solution at $\mathrm{pH} 7.0$ for extraction; the $\mathrm{pH}$ was determined in $0.01 \mathrm{~mol} \mathrm{~L}^{-1} \mathrm{CaCl}_{2} .2 \mathrm{H}_{2} \mathrm{O}$ solution and soil organic matter content (SOM) by wet combustion with sodium dichromate by colorimetry in a spectrophotometer (Cary 50, VARIAN $($ ) . The sum of bases $(\mathrm{SB}=\mathrm{Ca}+\mathrm{Mg}+\mathrm{K})$, cation exchange capacity $(\mathrm{CEC}=\mathrm{SB}+(\mathrm{H}+\mathrm{Al})$, and base saturation $(\mathrm{V} \%=(100 \mathrm{x} \mathrm{SB}) / \mathrm{CEC})$ were calculated.

The data initially subjected were to descriptive analysis, calculating the mean and standard deviation from the mean. The chemical, physical and morphological characteristics of the nanoparticles associated with the treatments analyzed were by multivariate techniques, using combined principal component and cluster analysis. By both techniques, the variables with mean zero and variance one (Hair Jr et al., 2005) were standardized.

Principal component analysis (PCA) applied was to identify and select the correlated soil quality indicator variables, capable of explaining the origin of the greatest variations in the data. The criterion for selecting the number of principal components were eigenvalues greater than 1 (one), that would account for more than $70 \%$ of the explanation of the total variance of the original data (Hair Jr et al., 2005). The importance of the variables in each principal component determined was by the correlation coefficient $r>0.5$ in module. As a complementary measure, cluster analysis applied was by the Ward algorithm method, to check the similarity between treatments and group formation. The similarity measure used was the mean Euclidean distance. For all multivariate statistical techniques, software STATISTICA 7.0 was used and the descriptive analyses by software EXCEL.

\section{Results and Discussion}

With the principal component analysis (PCA), it was possible to identify the components responsible for explaining most of the total variance, where the first one retained $57.50 \%$ of the total variance, the second $21.06 \%$, the third $10.30 \%$, and the fourth $6.54 \%$ (Table 2).

Although the eigenvalues of the four components were greater than one, only the first two were used to explain the original total variation (Figure 1), with a cumulative variance greater than 70\% (Hair Jr et al., 2005).

On the first component, the properties that indicated the soil quality and had the highest absolute correlation coefficients $(r>0.5)$ were all physical properties. The CEC was the only chemical property that did not reach the correlation coefficient ( $r>0.5$ ) and on this principal component, the Cerrado fragment area (Savannah) (T11) was the treatment with the highest correlation. However, none of the morphological nanostructures characteristics had satisfactory correlation indices.

On principal component one (PC1), located on the y-axis, antagonistic effects between some physical and chemical quality indicators were observed (Figure 1). Different from chemical properties, the physical properties of Cerrado soils generally indicate good natural conditions for agricultural exploitation (Lourente et al., 2011). Using principal component analysis (PCA), Pereira et al. (2010) observed a similar effect for soil physical properties in pasture and native forest (Cerrado). 
Table 2. Eigenvalues and percentage of variation explained by the first four principal components (PC) and classification of correlation coefficients between the soil quality indicators and principal components.

\begin{tabular}{|c|c|c|c|c|c|c|c|c|}
\hline Principal Component & PC 1 & & PC 2 & & PC 3 & & PC 4 & \\
\hline Eigenvalues & 10.35 & & 3.79 & & 1.85 & & 1.18 & \\
\hline (\%) explained & 57.50 & & 21.06 & & 10.30 & & 6.54 & \\
\hline Indicators & Correlation & Position & Correlation & Position & Correlation & Position & Correlation & Position \\
\hline Area $\left(\mathrm{nm}^{2}\right)$ & 0.077 & 17 & -0.908 & 1 & -0.393 & 5 & -0.113 & 9 \\
\hline Perimeter (nm) & 0.106 & 16 & -0.881 & 3 & -0.419 & 3 & -0.185 & 7 \\
\hline Feret $(\mathrm{nm})$ & 0.073 & 18 & -0.888 & 2 & -0.408 & 4 & -0.185 & 6 \\
\hline Circularity & -0.217 & 15 & -0.106 & 13 & -0.299 & 10 & 0.912 & 1 \\
\hline $\mathrm{P}\left(\mathrm{mg} \mathrm{dm}^{-3}\right)$ & 0.875 & 8 & 0.060 & 18 & -0.007 & 18 & -0.024 & 16 \\
\hline $\mathrm{K}\left(\mathrm{mmol}_{\mathrm{c}} \mathrm{dm}^{-3}\right)$ & 0.857 & 10 & -0.435 & 6 & 0.010 & 17 & 0.255 & 3 \\
\hline $\mathrm{Ca}\left(\mathrm{mmol}_{\mathrm{c}} \mathrm{dm}^{-3}\right)$ & 0.859 & 9 & 0.365 & 8 & -0.344 & 7 & -0.055 & 11 \\
\hline $\mathrm{Mg}\left(\mathrm{mmol}_{\mathrm{c}} \mathrm{dm}^{-3}\right)$ & 0.819 & 12 & 0.394 & 7 & -0.363 & 6 & -0.041 & 13 \\
\hline $\operatorname{CEC}\left(\mathrm{mmol}_{\mathrm{c}} \mathrm{dm}^{-3}\right)$ & 0.391 & 14 & 0.630 & 4 & -0.651 & 1 & -0.038 & 14 \\
\hline $\mathrm{pH}\left(\mathrm{CaCl}_{2}\right)$ & 0.973 & 2 & 0.095 & 14 & -0.012 & 16 & 0.116 & 8 \\
\hline $\mathrm{H}+\mathrm{Al}\left(\mathrm{mmol}_{\mathrm{c}} \mathrm{dm}^{-3}\right)$ & -0.944 & 4 & 0.185 & 10 & -0.197 & 12 & 0.003 & 18 \\
\hline $\operatorname{SOM}\left(\mathrm{g} \mathrm{dm}^{-3}\right)$ & -0.542 & 13 & 0.547 & 5 & -0.496 & 2 & -0.199 & 5 \\
\hline $\mathrm{SB}\left(\mathrm{mmol}_{\mathrm{c}} \mathrm{dm}^{-3}\right)$ & 0.877 & 7 & 0.330 & 9 & -0.337 & 8 & -0.029 & 15 \\
\hline $\mathrm{V}(\%)$ & 0.984 & 1 & -0.072 & 17 & 0.043 & 15 & 0.042 & 12 \\
\hline $\operatorname{Mac}\left(\mathrm{m}^{3} \mathrm{~m}^{-3}\right)$ & -0.928 & 6 & 0.091 & 16 & -0.302 & 9 & 0.087 & 10 \\
\hline $\operatorname{Mic}\left(m^{3} m^{-3}\right)$ & 0.843 & 11 & 0.132 & 12 & 0.291 & 11 & -0.281 & 2 \\
\hline $\mathrm{TP}\left(\mathrm{m}^{3} \mathrm{~m}^{-3}\right)$ & -0.935 & 5 & 0.089 & 15 & -0.054 & 14 & -0.225 & 4 \\
\hline $\mathrm{BD}\left(\mathrm{Mg} \mathrm{m}^{-3}\right)$ & 0.949 & 3 & -0.149 & 11 & 0.123 & 13 & 0.013 & 17 \\
\hline
\end{tabular}

Feret: Feret diameter; P: Phosphorus content; K: Potassium content; Ca: Calcium content; Mg: Magnesium content; CEC: Cation exchange capacity; pH: Hydrogenionic potential; H + Al: Potential acidity; SOM: Soil organic matter; SB: Sum of bases; V: Base saturation: Mac: Macroporosity; Mic: Microporosity; TP: Total porosity; BD: Soil Bulk density. Source: Authors.

With this antagonistic relationship in the physical properties and the spatial arrangement of the treatments, it was possible to analyze the current soil physical condition, which showed that the opposite positioning of T11 in relation to the other treatments was caused by impacts of agricultural practices (Souza \& Alves, 2003). Moreover, the soil physical condition sin treatment T8 were better than in the others (Figure 1 and Table 3).

For the chemical properties, the antagonistic effect of the chemical quality indicator variables was more evident between $(\mathrm{H}+\mathrm{Al})$ and the properties $\mathrm{pH}, \mathrm{V}, \mathrm{P}, \mathrm{Ca}, \mathrm{Mg}, \mathrm{SB}$, and $\mathrm{K}$. The Cerrado fragment (T11) mainly drove this antagonistic relation, where the values of most of the chemical soil quality indicators were lower than in the other areas (Table 3). This effect describes the natural soil properties of the Cerrado biome well, where fertility is low (Lopes and Guilherme, 2016). 
Figure 1. Biplot constructed with the first two principal components (soil surface conditions), showing the distribution of the physical, chemical and morphological properties of the nanoparticles as indicators of soil quality, under different conditions of the soil surface and vegetation cover.

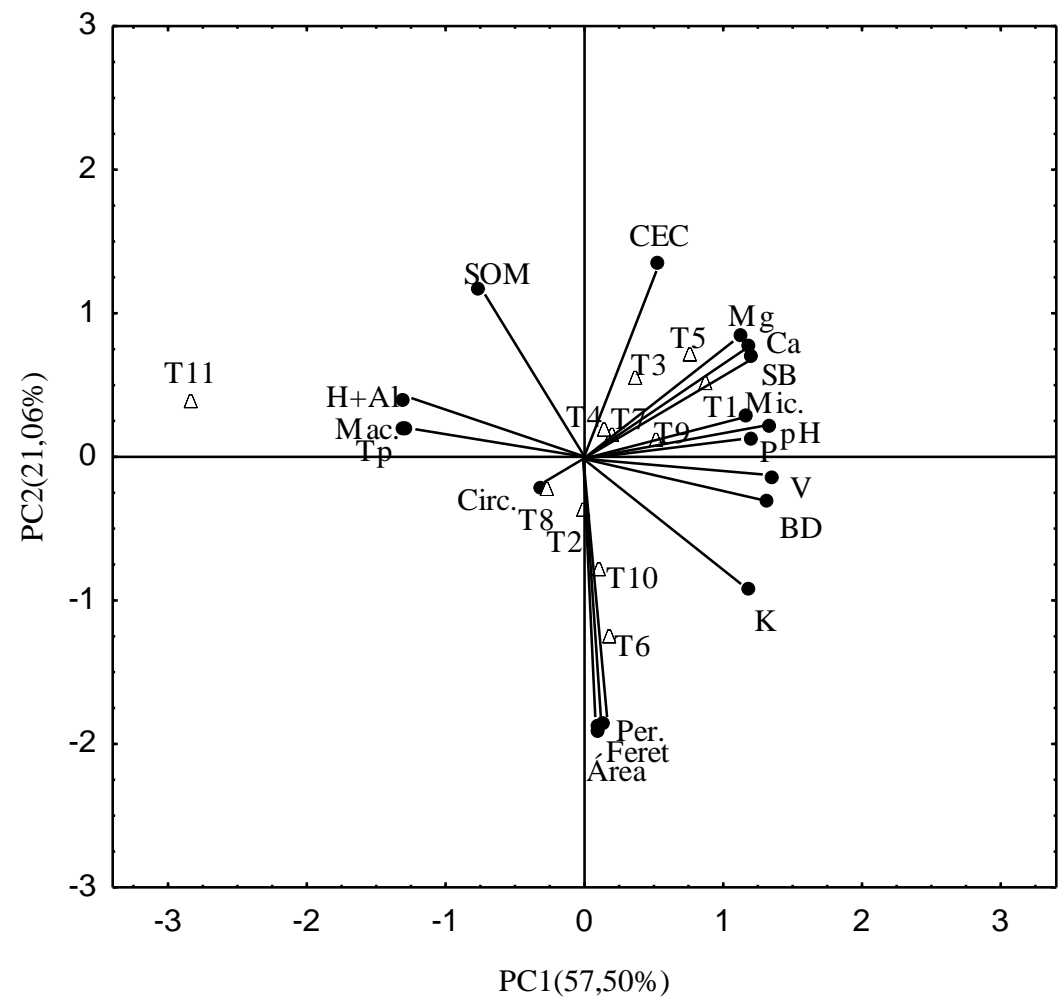

Source: Authors.

With this condition of poor natural fertility, the establishment of agricultural activities in the Cerrado requires the application of agricultural practices to establish satisfactory fertility levels, as those in the other areas of this study. In the notillage areas, the soil organic matter (SOM) content in NTS without chiseling was largely higher than in chiseled areas. This situation evidenced that chiseling influenced oxidation of SOM, derived from residues of the tested cover crops. According to Araujo et al. (2004) the environment in NTS areas without chiseling is less oxidative than in chiseled NTS areas.

In the second component (PC 2), located on the $\mathrm{x}$ axis, only the CEC, SOM and the morphological characteristics of the nanoparticles, such as area, perimeter and size (Feret diameter), had a satisfactory correlation coefficient ( $r>0.5)$. The chiseled area with the cover crop Pennisetum glaucum (T6) had this characteristic.

The separation process of soil nanoparticles and nanostructures was efficient, since the size of the particles analyzed in the micrographs (Figures 2 and 3) was smaller than 200nm (Table 3).

The mean sizes of the soil nanoparticles ranged from 54.2 to $90.4 \mathrm{~nm}$. In the areas without chiseling, the mean sizes ranged from 54.2 to $73.4 \mathrm{~nm}$, while in chiseled areas, from 54.9 to $90.4 \mathrm{~nm}$, and in the Cerrado fragment area (T11), the mean particle size was $62.8 \mathrm{~nm}$. Regarding the cover crops used the nanoparticle sizes in the treatments T3 and T4 with Cajanus cajan were the smallest (54.2 and $54.9 \mathrm{~nm}$, respectively). The mean sizes found confirmed the size range of 5 to $100 \mathrm{~nm}$, reported by Theng and Yuan (2008). These authors also stated that this size range is a typical characteristic of nanoparticles composed of $\mathrm{Fe}$ and $\mathrm{Al}$ oxides and hydroxides. 
Table 3. Descriptive statistics of chemical, physical and morphological characteristics of soil nanoparticles under different surface conditions and cover crops.

\begin{tabular}{|c|c|c|c|c|c|c|c|c|c|c|c|c|}
\hline \multirow{2}{*}{ Indicators } & & \multicolumn{11}{|c|}{ Treatment } \\
\hline & & $\mathrm{T} 1$ & $\mathrm{~T} 2$ & T3 & $\mathrm{T} 4$ & T5 & T6 & $\mathrm{T} 7$ & $\mathrm{~T} 8$ & T9 & $\mathrm{T} 10$ & $\mathrm{~T} 11$ \\
\hline \multirow{2}{*}{$\mathrm{P}\left(\mathrm{mg} \mathrm{dm}^{-3}\right)$} & $\overline{\bar{X}}$ & 40.3 & 38.5 & 36.0 & 49.8 & 56.8 & 40.8 & 41.0 & 31.5 & 48.8 & 38.5 & 10.0 \\
\hline & $\sigma$ & 6.9 & 27.3 & 14.0 & 13.3 & 20.8 & 9.4 & 16.2 & 9.7 & 22.5 & 9.5 & 3.4 \\
\hline \multirow{2}{*}{$\mathrm{K}\left(\mathrm{mmol}_{\mathrm{c}} \mathrm{dm}^{-3}\right)$} & $\bar{X}$ & 5.6 & 5.3 & 4.7 & 5.3 & 5.1 & 6.0 & 4.6 & 5.5 & 4.9 & 5.6 & 1.8 \\
\hline & $\sigma$ & 1.0 & 2.3 & 1.7 & 1.3 & 1.7 & 1.9 & 1.9 & 0.9 & 2.3 & 1.7 & 0.6 \\
\hline \multirow{2}{*}{$\mathrm{Ca}\left(\mathrm{mmol}_{\mathrm{c}} \mathrm{dm}^{-3}\right)$} & $\bar{X}$ & 47.8 & 32.0 & 35.3 & 30.3 & 47.8 & 28.8 & 35.0 & 30.5 & 41.0 & 33.0 & 16.0 \\
\hline & $\sigma$ & 8.1 & 6.2 & 16.9 & 4.0 & 19.6 & 6.1 & 13.2 & 4.1 & 20.7 & 0.8 & 6.0 \\
\hline \multirow{2}{*}{$\operatorname{Mg}\left(\mathrm{mmol}_{\mathrm{c}} \mathrm{dm}^{-3}\right)$} & $\bar{X}$ & 31.0 & 25.3 & 26.8 & 20.8 & 33.0 & 20.3 & 23.5 & 23.5 & 28.8 & 23.0 & 14.0 \\
\hline & $\sigma$ & 5.6 & 4.8 & 13.2 & 3.0 & 13.7 & 4.9 & 8.4 & 2.4 & 13.5 & 4.6 & 4.3 \\
\hline \multirow{2}{*}{$\mathrm{CEC}\left(\mathrm{mmol}_{\mathrm{c}} \mathrm{dm}^{-3}\right)$} & $\bar{X}$ & 106.8 & 85.3 & 84.4 & 78.6 & 106.1 & 74.0 & 84.1 & 82.0 & 94.9 & 84.4 & 83.8 \\
\hline & $\sigma$ & 20.6 & 8.3 & 32.2 & 6.8 & 27.2 & 5.6 & 23.0 & 5.3 & 30.5 & 10.5 & 13.1 \\
\hline \multirow{2}{*}{$\mathrm{pH}\left(\mathrm{CaCl}_{2}\right)$} & $\bar{X}$ & 6.2 & 5.6 & 6.0 & 5.8 & 6.1 & 5.7 & 5.6 & 5.8 & 5.9 & 5.8 & 4.5 \\
\hline & $\sigma$ & 0.4 & 0.2 & 0.3 & 0.4 & 0.5 & 0.4 & 0.5 & 0.4 & 0.3 & 0.4 & 0.2 \\
\hline \multirow{2}{*}{$\mathrm{H}+\mathrm{Al}\left(\mathrm{mmol}_{\mathrm{c}} \mathrm{dm}^{-3}\right)$} & $\bar{X}$ & 22.5 & 22.8 & 17.8 & 22.3 & 20.3 & 19.0 & 21.0 & 22.5 & 20.3 & 22.8 & 52.0 \\
\hline & $\sigma$ & 10.8 & 5.1 & 3.1 & 2.0 & 7.4 & 7.4 & 4.2 & 4.6 & 5.6 & 5.7 & 2.9 \\
\hline \multirow{2}{*}{$\operatorname{SOM}\left(\mathrm{g} \mathrm{dm}^{-3}\right)$} & $\bar{X}$ & 28.3 & 25.0 & 27.3 & 25.8 & 30.0 & 24.3 & 25.3 & 26.0 & 31.5 & 26.5 & 35.0 \\
\hline & $\sigma$ & 1.0 & 1.5 & 1.9 & 1.7 & 3.7 & 1.8 & 6.8 & 2.9 & 2.1 & 1.8 & 9.2 \\
\hline \multirow{2}{*}{$\mathrm{SB}\left(\mathrm{mmol}_{\mathrm{c}} \mathrm{dm}^{-3}\right)$} & $\bar{X}$ & 84.3 & 62.5 & 66.7 & 56.3 & 85.9 & 55.0 & 63.1 & 59.5 & 74.7 & 61.6 & 31.8 \\
\hline & $\sigma$ & 14.5 & 12.5 & 31.4 & 7.6 & 33.0 & 12.6 & 23.4 & 5.6 & 36.0 & 5.3 & 10.8 \\
\hline \multirow{2}{*}{$\mathrm{V}(\%)$} & $\bar{X}$ & 79.5 & 73.3 & 76.3 & 71.3 & 79.3 & 74.0 & 74.5 & 72.5 & 74.3 & 73.0 & 38.0 \\
\hline & $\sigma$ & 7.0 & 9.7 & 10.5 & 4.2 & 11.9 & 11.4 & 16.7 & 4.7 & 18.5 & 3.5 & 10.5 \\
\hline \multirow{2}{*}{ Mac. $\left(\mathrm{m}^{3} \mathrm{~m}^{-3}\right)$} & $\bar{X}$ & 0.09 & 0.10 & 0.07 & 0.07 & 0.09 & 0.08 & 0.08 & 0.13 & 0.08 & 0.11 & 0.22 \\
\hline & $\sigma$ & 0.05 & 0.05 & 0.02 & 0.06 & 0.03 & 0.04 & 0.02 & 0.04 & 0.02 & 0.04 & 0.024 \\
\hline \multirow{2}{*}{ Mic. $\left(\mathrm{m}^{3} \mathrm{~m}^{-3}\right)$} & $\bar{X}$ & 0.36 & 0.33 & 0.36 & 0.34 & 0.34 & 0.35 & 0.35 & 0.31 & 0.34 & 0.33 & 0.29 \\
\hline & $\sigma$ & 0.02 & 0.04 & 0.02 & 0.03 & 0.02 & 0.03 & 0.02 & 0.02 & 0.02 & 0.02 & 0.002 \\
\hline \multirow{2}{*}{$\mathrm{TP}\left(\mathrm{m}^{3} \mathrm{~m}^{-3}\right)$} & $\bar{X}$ & 0.40 & 0.43 & 0.43 & 0.42 & 0.43 & 0.43 & 0.43 & 0.44 & 0.42 & 0.43 & 0.51 \\
\hline & $\sigma$ & 0.04 & 0.02 & 0.02 & 0.03 & 0.02 & 0.02 & 0.02 & 0.03 & 0.02 & 0.03 & 0.026 \\
\hline \multirow{2}{*}{$\mathrm{BD}\left(\mathrm{Mg} \mathrm{m}^{-3}\right)$} & $\bar{X}$ & 1.51 & 1.42 & 1.49 & 1.49 & 1.46 & 1.47 & 1.48 & 1.42 & 1.50 & 1.52 & 1.16 \\
\hline & $\sigma$ & 0.07 & 0.08 & 0.10 & 0.05 & 0.03 & 0.04 & 0.06 & 0.10 & 0.06 & 0.07 & 0.008 \\
\hline \multirow{2}{*}{ Area $\left(\mathrm{nm}^{2}\right)$} & $\bar{X}$ & 2245.3 & 2982.3 & 1618.3 & 1754.0 & 2180.5 & 4176.4 & 2082.1 & 2745.5 & 2928.0 & 3767.2 & 2136.4 \\
\hline & $\sigma$ & 1900.4 & 3132.6 & 1955.8 & 2379.1 & 2165.0 & 3070.9 & 3241.9 & 2687.7 & 2839.7 & 2567.1 & 2317.3 \\
\hline \multirow{2}{*}{ Perimeter (nm) } & $\bar{X}$ & 179.3 & 206.1 & 150.2 & 150.3 & 175.6 & 255.0 & 170.7 & 186.5 & 201.4 & 236.6 & 170.1 \\
\hline & $\sigma$ & 67.6 & 88.5 & 76.1 & 81.0 & 79.6 & 87.4 & 117.8 & 89.4 & 89.2 & 76.0 & 76.8 \\
\hline \multirow{2}{*}{ Feret (nm) } & $\bar{X}$ & 65.1 & 75.2 & 54.2 & 54.9 & 61.8 & 90.4 & 63.7 & 67.5 & 73.4 & 86.1 & 62.8 \\
\hline & $\sigma$ & 24.2 & 32.5 & 27.2 & 28.6 & 27.9 & 31.0 & 46.2 & 31.7 & 32.7 & 27.0 & 28.1 \\
\hline \multirow{2}{*}{ Circularity } & $\bar{X}$ & 0.79 & 0.78 & 0.74 & 0.79 & 0.75 & 0.76 & 0.73 & 0.80 & 0.77 & 0.77 & 0.78 \\
\hline & $\sigma$ & 0.1 & 0.1 & 0.2 & 0.1 & 0.1 & 0.2 & 0.2 & 0.1 & 0.1 & 0.1 & 0.1 \\
\hline
\end{tabular}

T1: Crotalaria juncea in NTS without chiseling; T2: Crotalaria juncea in NTS with chiseling; T3: Cajanus cajan in NTS without chiseling; T4: Cajanus cajan in NTS with chiseling; T5: Pennisetum glaucum in NTS without chiseling; T6: Pennisetum glaucum in NTS with chiseling; T7: Fallow in NTS without chiseling; T8: Fallow in NTS with chiseling; T9: Urochloa ruziziensis in NTS without chiseling; T10: Urochloa ruziziensis in NTS with chiseling; T11: Cerrado fragment, $(\mathrm{X})$ : Mean; $\sigma$ : Standard deviation; Feret: Feret diameter; P: Phosphorus content; K: Potassium content; Ca: Calcium content; Mg: Magnesium content; CEC: Cation exchange capacity; pH: Hydrogenionic potential; H + Al: Potential acidity; SOM: Soil organic matter; SB: Sum of bases; V: Base Saturation: Mac: Macroporosity; Mic: Microporosity; TP: Total porosity; BD: Soil Bulk Density. Source: Authors. 
In the micrographs of all studied areas, the presence of hexagon-like nanoparticles, with regular edges, well-defined vertices, and opaque color observed (Figures 2 and 3). These are similar morphological characteristics to those described by Tsao et al. (2012) and Tsao et al. (2013), indicating kaolinite nanoparticles, although Santos et al. (2006) claimed that the morphology of kaolinite is similar to that of gibbsite, a common mineral in Latosol soils (Eberhardt et al., 2008). The opaque color of these nanoparticles is due to their low thickness under the electron beam transmitted by the microscope to take the micrographs (Pédrot et al., 2011).

Another type of nanoparticle/nanostructures formed has darker colors, with no definition of edges and a lumpy shape (Figures 2 and 3). This shape description resembles that in the study of Ghezzi et al. (2014), who related it to Fe oxides. In almost all treatments except T6, the hexagonal and lumpy nanoparticles seem interconnected in some places. These apparently formed nanostructures have a morphology similar to that described by Wei et al. (2012) when studying the mechanisms of interaction and stability between kaolinites and synthetic Fe oxides (goethite), promoted by electrostatic attraction.

The morphological characteristics area, perimeter and Feret diameter (size) strongly correlated were with each other (Figure 1). Area and perimeter measured by a two-dimensional projection of the nanoparticles by the TEM micrographs and only used to define the circularity.

The mean circularity index of the nanoparticles varied from 0.73 to 0.80 . This morphological feature is used in nanoscience to describe the shape of nanoparticles and how closely it resembles a perfect sphere, with a circularity index equal to one (Muscas et al., 2015). It expected to find a more pronounced effect of the circularity of the nanoparticles in response to the studied treatments. In some areas of nanotechnology, the circularity effect of nanoparticles modifies the properties, affecting the material performance (Ahmed et al., 2016). Perhaps this morphological characteristic has greater variability and influences the behavior of soil nanoparticles, in comparisons of different classes of soils, layers, mineralogy, and other conditions.

After analyzing the results of the principal components, the hierarchical grouping analysis was applied with the variables with correlation coefficients ( $r>0.5$ ) for the first component (Figure 4a), the second component (Figure 4b), and both together (Figure 4c).

On the first component, the main discriminant variables ( $>$ 0.5) formed four groups (Figure 4a), evidencing the dissimilarity of the Cerrado area with all other treatments. This situation may have resulted mainly from the indicators of chemical and physical quality. The grouping analysis showed that the treatments T2, T8 and T10 that form group G2 are the most similar to each other. These treatments influenced the physical indicators most positively (Table 3). In T2, better physical properties observed, mainly a reduction in density, which demonstrates the effect of chiseling with planting of Crotalaria juncea. These results corroborate those of Pacheco et al. (2015), who emphasized the positive effect of Crotalaria juncea on compaction and those of Seki et al. (2015) who observed the beneficial effect of soil chiseling on soil bulk density.

In the group $\mathrm{G} 4$, comprising $\mathrm{T} 1$, $\mathrm{T} 5$ and $\mathrm{T} 9$, the values for the chemical properties were relevant, especially for CEC and SOM (Table 3). According to Rosa et al. (2017), the increase in soil fertility by planting cover crops is related to the fulvic acid content in SOM.

Along the second principal component, four groups were formed (Figure 4b). However, in the group G4, similarity of the Cerrado fragment with treatments T1, T5 and T9 observed, both of which not chiseled. An analysis of the micrographs (Figure 2A, C and E) showed that this similarity resulted from the size and interconnections between the nanoparticles of the possible Fe oxides and Al/Kaolinite hydroxides. Aside from the electrostatic attraction mechanism influencing this connection, it is worth mentioning that the most marked effect in these treatments may have occurred as a function of SOM, which was not removed from the analyzed samples in this study. According to Adhikari and Yang, (2015) Adhiraki and Yang (2015) and 
Pédrot et al. (2011), organic substances interact with inorganic nanoparticles, which is an effect that explains the treatments T1, T5, T9, and T11, forming group G4. Interestingly, in the NTS treatments with chiseling, SOM oxidation may have been higher than in the other treatments.

Figure 2. Micrographs by transmission electron microscopy (TEM) of nanostructures of a typical clayey Oxisol under different cover crops, (a) T1: Crotalaria juncea in NTS without chiseling; (b) T3: Cajanus cajan in NTS without chiseling; (c) T5: Pennisetum glaucum in NTS without chiseling; (d) T7: Fallow of NTS without chiseling; (e) T9: Urochloa ruziziensis in NTS without chiseling and (f) T11: Cerrado fragment; Green arrows indicate nanoparticles of Al hydroxide oxide and blue arrows indicate Fe oxide.
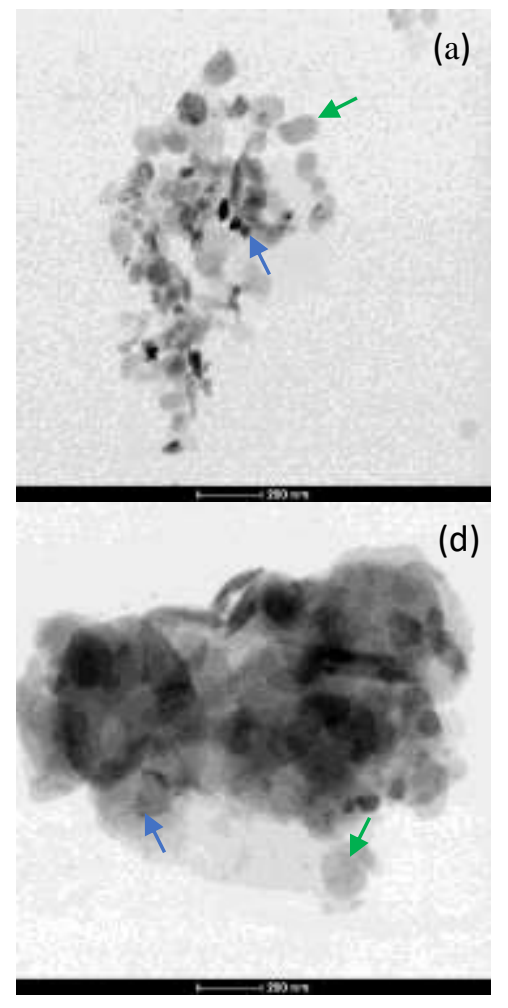

(d)

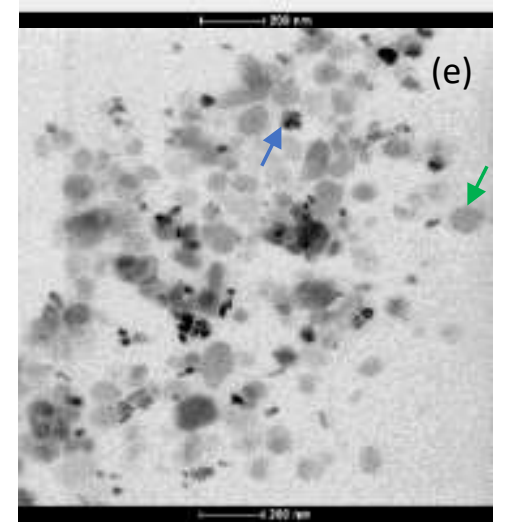

Source: Authors. (b)
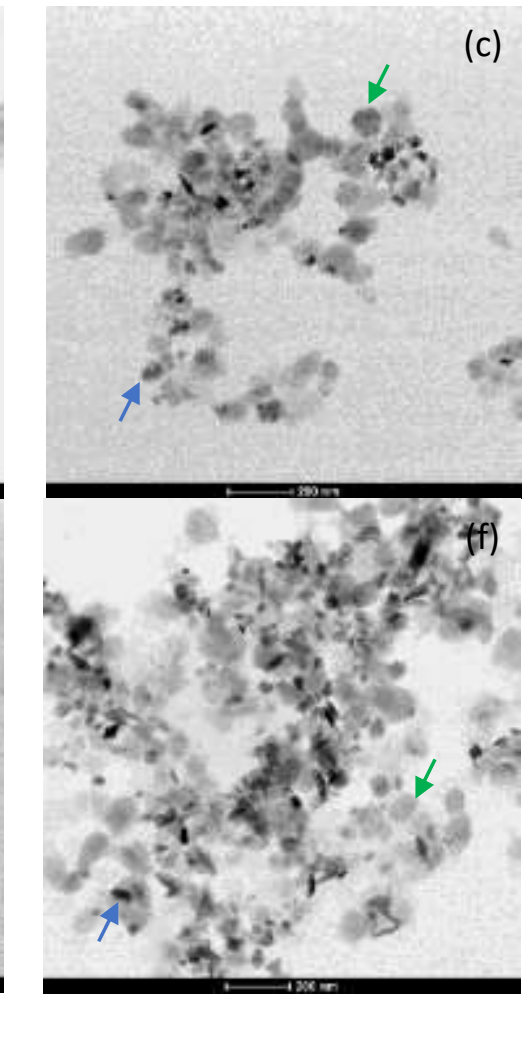

(c)

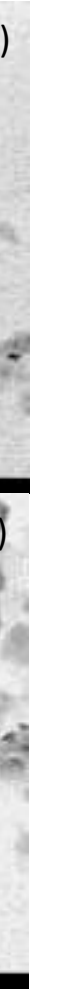

Another important point is the relationship between CEC, SOM and the morphological characteristics of the nanoparticles, because when there is an increase in SOM, there is a reduction in the nanoparticle size and concomitantly an increase in CEC. This behavior leads us to believe that with the size reduction, the nanoparticle surface area increases, facilitating the interaction of SOM with the nanoparticle surface, as suggested by Calabi-Floody et al. (2011).

Clustering of the discriminant variables of the two principal components formed five groups (Figure 4c), showing again that the Cerrado fragment has no similarity with any other treatment. Hierarchical clustering analysis as a supplementary tool for the interpretation of the principal component analysis results showed that only the physical and chemical soil quality indicators do not have the necessary sensitivity to verify small changes caused by the crop systems. 
Figure 3. Micrographs by transmission electron microscopy (TEM) of nanostructures of a typical clayey Oxisol under different cover crops, (a) T2: Crotalaria juncea in NTS with chiseling; (b) T4: Cajanus cajan in NTS with chiseling; (c) T6: Pennisetum glaucum in NTS with chiseling; (d) T8: Fallow inNTS with chiseling; (e) T10: Urochloa ruziziensis in NTS with chiseling and (f) T11: Cerrado fragment; Green arrows indicate nanoparticles of Al hydroxide oxide and blue arrows indicate Fe oxide.

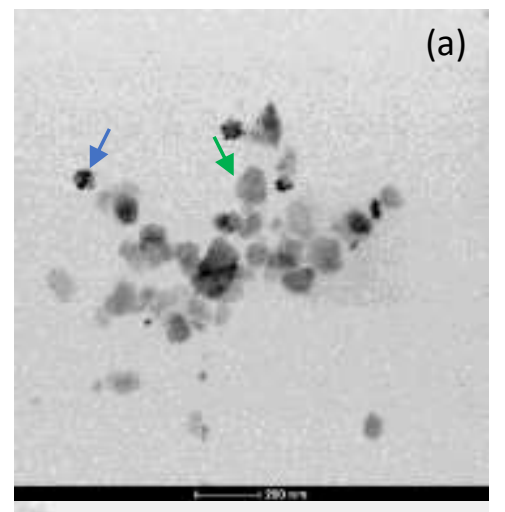

(d)

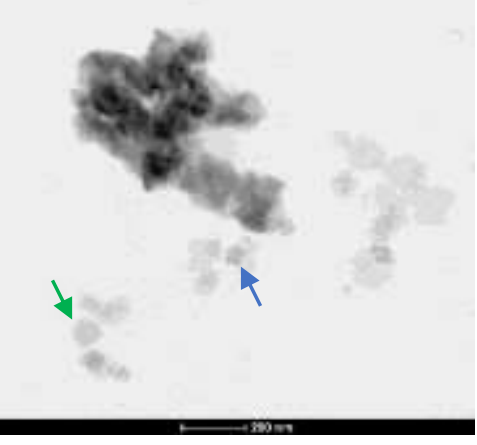

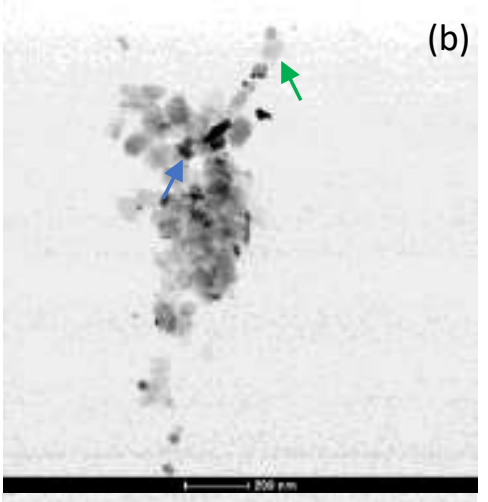

(e)

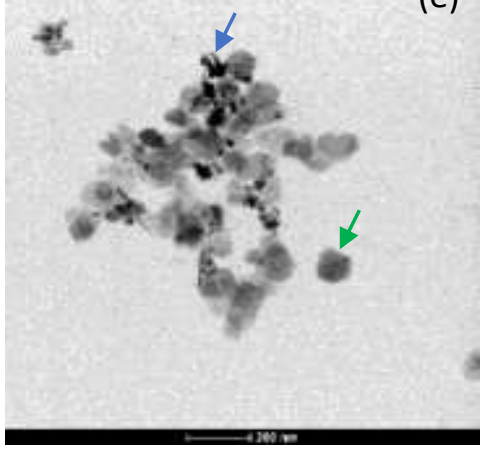

Source: Authors. (c)

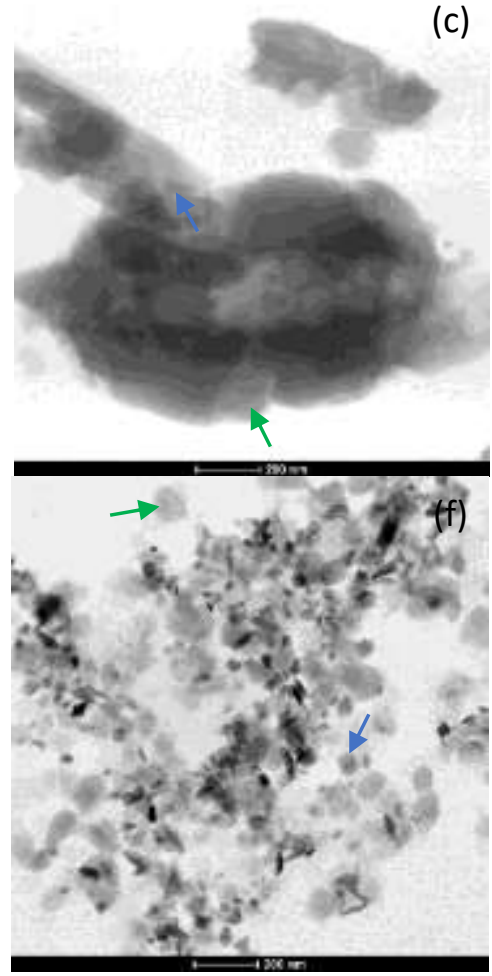


Figure 4. Dendrogram of treatment similarity according to the distinctive quality indicators $(r>0.5)$ of the first principal component (a); second principal component (b); first and second principal components (c). T1: Crotalaria juncea in NTS without chiseling; T2: Crotalaria juncea in NTS with chiseling; T3: Cajanus cajan in NTS without chiseling; T4: Cajanus cajan in NTS with chiseling; T5: Pennisetum glaucum in NTS without chiseling; T6: Pennisetum glaucum in NTS with chiseling; T7: Fallow in NTS without chiseling; T8: Fallow in NTS with chiseling; T9: Urochloa ruziziensis in NTS without chiseling; T10: Urochloa ruziziensis in NTS with chiseling; T11: Cerrado fragment.
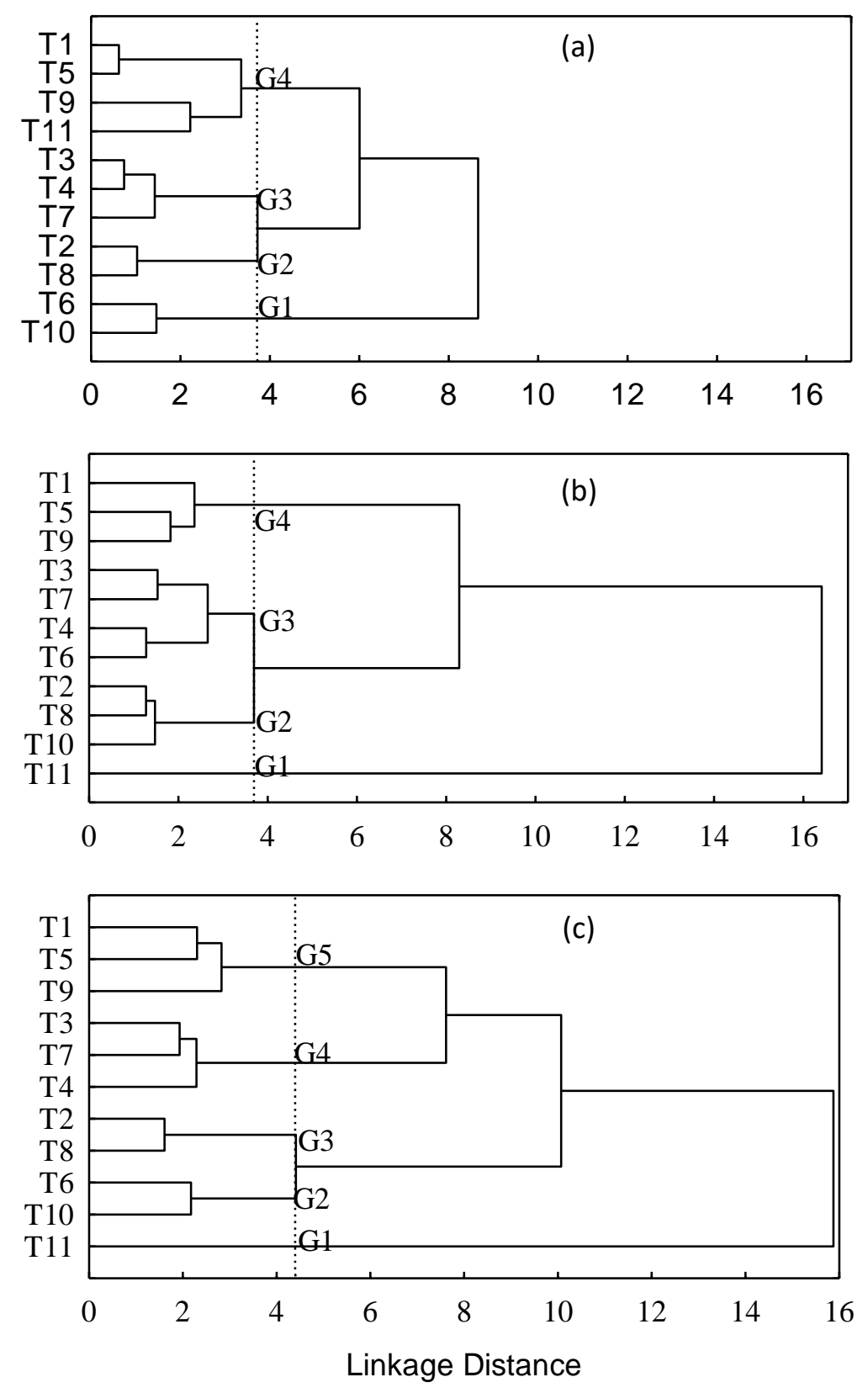

Source: Authors.

\section{Conclusion}

Chiseling and planting of Crotalaria juncea as cover crop induced improvements in the soil physical properties 
macroporosity, microporosity and soil bulk density, compared to the original condition.

Vegetation cover and non-chiseling of the soil induced increases in the soil chemical properties $\mathrm{P}, \mathrm{K}$, and $\mathrm{Mg}$ contents, $\mathrm{pH}$, and soil organic matter.

Crotalaria juncea and Pennisetum glaucum stood out among the cover crops with positive influences on the soil chemical and physical properties.

The morphological characteristics of the nanostructures as a good soil quality indicator, complementary to the chemical indicators, for being sensitive in the detection of changes in soil properties in the short-term.

\section{Acknowledgments}

The authors wish to thank the National Council for Scientific and Technological Development (CNPq) for the financial support with the funding of the project and the Coordination for the Improvement of Higher Education Personnel (CAPES) for the doctoral scholarship of the first author.

\section{References}

Adhikari, D. \& Yang, Y. (2015). Selective stabilization of aliphatic organic carbon by iron oxide. Scientific Reports, $5,11214$.

Ahmed, B., Kumar, S., Kumar, S. \& Ojha, A. K. (2016). Shape induced (spherical, sheets and rods) optical and magnetic properties of CdS nanostructures with enhanced photocatalytic activity for photodegradation of methylene blue dye under ultra-violet irradiation. Journal of Alloys Compounds, 679, 324-334.

Alves, M. C., Carvalho, M. P. \& Souza, E. J. (2015). Manejo do solo, in: Arf, O., Lemos, L. B., Sorrato, R. P., \& Ferrari, S. (Eds.), Aspectos Gerais da Cultura do Feijão Phaseolus vulgaris L. FEPAF, 39-63.

Araujo, M. A., Tormena, C. A., Inoue, T. T. \& Costa, A. C. S. (2004). Efeitos da escarificação na qualidade física de um Latossolo Vermelho distroférrico após treze anos de semeadura direta. Revista Brasileira de Ciência do Solo, 28, 495-504.

Archanjo, B. S., Mendoza, M. E., Albu, M., Mitchell, D. R. G., Hagemann, N., Mayrhofer, C., Mai, T. L. A., Weng, Z., Kappler, A., Behrens, S., Munroe, P., Achete, C. A., Donne, S., Araujo, J. R., van Zwieten, L., Horvat, J., Enders, A. \& Joseph, S. (2017). Nanoscale analyses of the surface structure and composition of biochars extracted from field trials or after co-composting using advanced analytical electron microscopy. Geoderma, $294,70-79$.

Arora, A., Singh, B. \& Kaur, P. (2019). Performance of Nano-particles in stabilization of soil: a comprehensive review. Materials Today: Proceedings, 17, $124-130$.

Calabi-Floody, M., Bendall, J. S., Jara, A. A., Welland, M. E., Theng, B. K. G., Rumpel, C. \& Mora, M. de la L. (2011). Nanoclays from an Andisol: Extraction, properties and carbon stabilization. Geoderma, 161, 159-167.

Calonego, J. C., Gil, F. C., Rocco, V. F. \& Santos, E. A. (2012). Persistence and nutrient release from maize, brachiaria and lablab straw. Bioscience Journal, $28,770-781$.

Chen, G. \& Weil, R. R. (2010). Penetration of cover crop roots through compacted soils. Plant Soil, 331, 31-43.

Claessen, M. E. C. (1997). Manual de métodos de análise de solo, (2nd ed.), EMBRAPA. Centro Nacional de Pesquisa de Solos

Costa, N. R., Andreotti, M., Buzetti, S., Lopes, K. S. M., Santos, F. G. dos \& Pariz, C. M. (2014). Acúmulo de macronutrientes e decomposição da palhada de braquiárias em razão da adubação nitrogenada durante e após o consórcio com a cultura do milho. Revista Brasileira de Ciência do Solo, 38, $1223-1233$.

Drescher, M. S., Eltz, F. L. F., Denardin, J. E. \& Faganello, A. (2011). Persistência do efeito de intervenções mecânicas para a descompactação de solos sob plantio direto. Revista Brasileira de Ciência do Solo, 35, 1713-1722.

Eberhardt, D. N., Vendrame, P. R. S., Becquer, T. \& De Fátima Guimarães, M. (2008). Influência da granulometria e da mineralogia sobre a retenção do fósforo em latossolos sob pastagens no cerrado. Revista Brasileira de Ciência do Solo, 32, 1009-1016.

Edwards, A. P. \& Bremmer, J. M. (1967). Dispersion of soil particles by sonic vibration. Journal of Soil Science, $18,47-63$.

Feng, W., Klaminder, J. \& Boily, J. F. (2015). Thermal Stability of Goethite-Bound Natural Organic Matter Is Impacted by Carbon Loading. The Journal of Physical and Chemistry, A 119, 12790-12796.

Freddi, O. D. S., Centurion, J. F., Beutler, A. N., Aratani, R. G. \& Leonel, C. L. (2007). Compactação do solo no crescimento radicular e produtividade da cultura do milho. Revista Brasileira de Ciência do Solo, 31, 627-636.

Ghezzi, J. L., Karathanasis, A. D., Matocha, C. J., Unrine, J. \& Thompson, Y. L. (2014). Characterization of environmental nano- and macrocolloid particles extracted from selected soils and biosolids. Applied and Environmental Soil Science, 1, 1.

Hair Jr, J. F., Anderson, R. E., Tatham, R. L. \& Black, W. C. (2005). Análise Multivariada de dados, (5th ed.), Bookman. 
Hochella, M. F., Lower, S. K., Maurice, P. A., Penn, R. L., Sahai, N., Sparks, D. L. \& Twining, B. S. (2008). Nanominerals, Mineral Nanoparticles, and Earth Systems. Science, (80) 319, 1631-1635.

Javed, Z., Dashora, K., Mishra, M., Fasake, V. D. \& Srivastva, A. (2019). Effect of accumulation of nanoparticles in soil health- a concern on future. Frontiers in Nanoscience and Nanotechnology, 5, 1-9.

Keiluweit, M., Bougoure, J. J., Zeglin, L. H., Myrold, D. D., Weber, P. K., Pett-Ridge, J., Kleber, M. \& Nico, P. S. (2012). Nano-scale investigation of the association of microbial nitrogen residues with iron (hydr)oxides in a forest soil O-horizon. Geochimica et Cosmochimica Acta, 95, $213-226$.

Lopes, A. S. \& Guilherme, L. R. G. (2016). A career perspective on soil management in the Cerrado region of Brazil, Advances in Agronomy, 137, 1-72.

Lourente, E. R. P., Mercante, F. M., Alovisi, A. M. T., Gomes, C. F., Gasparini, A. S. \& Nunes, C. M. (2011). Atributos Microbiológicos, Químicos E Físicos De Solo Sob Diferentes Sistemas De Manejo E Condições De Cerrado. Pesquisa Agropecuária Tropical, 41, 20-28.

Mateus, G. P. \& Santos, N. C. B. dos (2012). Sistema Plantio Direto E a Conservação Dos Recursos Naturais. Pesquisa Tecnológica, 9 , 5.

Mioranza, D., Rosa, H. A., Assmann, E. J., Secco, D., Simonetti, A. P. M. M. \& Moreira, C. R. (2015). Alterações estruturais de um Latossolo argiloso sob plantio direto induzidas pela intensidade de tráfego de um trator. Revista Agropecuária Tecnológica, 36, 203-211.

Muscas, G., Singh, G., Glomm, W. R., Mathieu, R., Kumar, P. A., Concas, G., Agostinelli, E. \& Peddis, D. (2015). Tuning the size and shape of oxide nanoparticles by controlling oxygen content in the reaction environment: Morphological analysis by aspect maps. Chemistry of Materials, 27, $1982-1990$.

Nascimento, V. do, Arf, O., Tarsitano, M. A. A., Garcia, N. F. S., Penteado, M. de S. \& Sabundjian, M. T. (2016). Economic analysis of rice and common bean production in succession to green manure crops and mecahnical soil decompression in Brazilian Savannah. Revista Ceres, 63, 315-322.

Nicoloso, R. da S., Amado, T. J. C., Schneider, S., Lanzanova, M. E., Girardello, V. C. \& Bragagnolo, J. (2008). Eficiência da escarificação mecânica e biológica na melhoria dos atributos físicos de um latossolo muito argiloso e no incremento do rendimento de soja. Revista Brasileira de Ciência do Solo, 32 , $1723-1734$

Nunes, M. R., Pauletto, E. A., Denardin, J. E., Faganello, A., Pinto, L. F. S. \& Scheunemann, T. (2014). Persistência dos efeitos da escarificação sobre a compactação de Nitossolo sob plantio direto em região subtropical úmida. Pesquisa Agropecuária Brasileira, 49, 531-539.

Pacheco, L. P., Miguel, A. S. D. C. S., Bonfim-Silva, E. M., Souza, E. D. de \& Silva, F. D. da (2015). Influência da densidade do solo em atributos da parte aérea e sistema radicular de crotalária. Pesquisa Agropecuária Tropical, 45, 464-472.

Pédrot, M., Boudec, A. Le, Davranche, M., Dia, A. \& Henin, O. (2011). How does organic matter constrain the nature, size and availability of Fe nanoparticles for biological reduction? Journal Colloid Interface Science, 359, 75-85.

Pereira, S. A., Oliveira, G. C. de, Severiano, E. da C., Balbino, L. C. \& Oliveira, J. P. de (2010). Análise de componentes principais dos atributos físicos de um Latossolo Vermelho Distrófico típico sob pastagem e mata. Global Science and Technology, 3, 87-97.

Reichert, J. M., Suzuki, L. E. A. S., Reinert, D. J., Horn, R. \& Håkansson, I. (2009). Reference bulk density and critical degree-of-compactness for no-till crop production in subtropical highly weathered soils. Soil Tillage Research, 102, 242-254.

Ribeiro, B. T., Junqueira, B. R. \& Rodrigues, G. I. (2014). Extração de fósforo disponível em um Latossolo assistida por irradiação ultrassônica Ultrasoundassisted extraction of available P from a. Amazonian Journal of Agricultural and Environment Science, 57, 382-387.

Rice, S. B., Chan, C., Brown, S. C., Eschbach, P., Han, L., Ensor, D. S., Stefaniak, A. B., Bonevich, J., Vladár, A. E., Hight Walker, A. R., Zheng, J., Starnes, C., Stromberg, A., Ye, J. \& Grulke, E. A. (2013). Particle size distributions by transmission electron microscopy: an interlaboratory comparison case study. Metrologia.

Rosa, D. M., Nobrega, L. H. P., Mauli, M. M., Lima, G. P. de \& Pacheco, F. P. (2017). Substâncias húmicas do solo cultivado com plantas de cobertura em rotação com milho e soja. Revista Ciência Agronômica, 48, 221-230.

Sá, M. A. C. D. \& Lima, J. M. D. (2005). Energia ultra-sônica: uma ferramenta em ciência do solo. Planaltina.

Santos, G. G., Silveira, P. M. da, Marchão, R. L., Petter, F. A. \& Becquer, T. (2012). Atributos químicos e estabilidade de agregados sob diferentes culturas de cobertura em Latossolo do cerrado. Revista Brasileira de Engenharia Agrícola e Ambiental, 16, 1171-1178.

Santos, H. S., Kiyohara, P., Coelho, A. C. V. \& Santos, P. S. (2006). Estudo por microscopia eletrônica das transformąões durante a queima de argilas altamente aluminosas brasileiras. Ceramica, 52, 125-137.

Schneider, C. A., Rasband, W. S. \& Eliceiri, K. W. (2012). NIH Image to ImageJ: 25 years of image analysis. Nature Methods, 9, 671-675.

Secco, D., Bassegio, D., Villa, B. de, Marins, A. C. de, Zanão Junior, L. A., Silva, T. R. B. da, Souza, S. N. M. da. (2021). Crambe oil yield and soil physical properties responses to no-tillage, cover crops and chiseling. Industrial Crops \& Products, 161, 113174.

Seki, A. S., Seki, F. G., Jasper, S. P., Silva, P. R. A. \& Benez, S. H. (2015). Effects of soil decompaction techniques in an area under a system of direct seeding. Revista Ciência Agronômica, 46, 460-468.

Shen, Y. H. (1999). Sorption of humic acid to soil: The role of mineralogical composition. Chemosphere, 38, 2489-2499.

Silva, A. P., Imhoff, S. \& Kay, B. (2004). Plant response to mechanical resistance and air-filled porosity of soils under conventional and no-tillage system. Scientia Agricola, 61, 451-456. 
Research, Society and Development, v. 10, n. 3, e15910313070, 2021

(CC BY 4.0) | ISSN 2525-3409 | DOI: http://dx.doi.org/10.33448/rsd-v10i3.13070

Souto Filho, S. N., Alves, M. C., Monreal, C. M. \& Bonini, C. S. B. (2017). Nanoparticles and nanostructure morphology of a Red Latosol in rehabilitation. Revista Brasileira de Engenharia Agrícola e Ambiental, 530-536.

Souza, Z. M. de \& Alves, M. C. (2003). Propriedades Químicas De Um Latossolo Vermelho Distrófico De Cerrado Sob Diferentes Usos E Manejos. Revista Brasileira de Ciência do Solo, 133-139.

Tang, Z., Wu, L., Luo, Y. \& Christie, P. (2009). Size fractionation and characterization of nanocolloidal particles in soils. Environmental Geochemistry Health, 31, 1-10.

Theng, B. K. G. \& Yuan, G., 2008. Nanoparticles in the soil environment. Elements, 4, 395-399.

Tsao, T. M., Chen, Y. M., Sheu, H. S., Zhuang, S. Y., Shao, P. H., Chen, H. W., Shea, K. S., Wang, M. K., Shau, Y. H. \& Chiang, K. Y. (2012). Red soil chemistry and mineralogy reflect uniform weathering environments in fluvial sediments, Taiwan. Journal of Soils Sediments, 12, 1054-1065.

Tsao, T. M., Wang, Y. N., Chen, Y. M., Chou, Y. M. \& Wang, M. K. (2013). Automated ultrafiltration device for environmental nanoparticle research and implications: A review. Micromachines, 4, 215-231.

Vendrame, P. R. S., Eberhardt, D. N., Brito, O. R., Marchão, R. L., Quantin, C. \& Becquer, T. (2011). Formas de ferro e alumínio e suas relações com textura, mineralogia e Carbono Orgânico em latossolos do cerrado. Semina Agraria, 32, 1657-1666.

Wei, S., Tan, W., Zhao, W., Yu, Y., Liu, F. \& Koopal, L. K. (2012). Microstructure, Interaction Mechanisms, and Stability of Binary Systems Containing Goethite and Kaolinite. Soil Science Society of America Journal, 76, 389.

WRB-IUSS. 2015. World Reference Base for Soil Resources (WRB), Sistema Universal Reconhecido pela International Union of Soil Science (IUSS) e FAO. Disponível em: <http://www.fao.org/3/a-i3794e.pdf. 